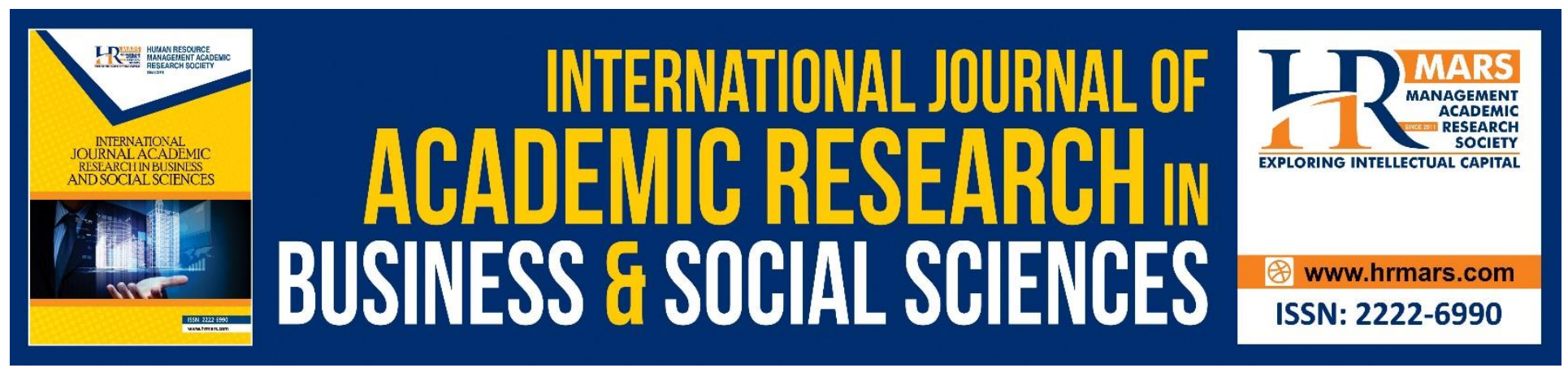

\title{
Personality Traits and its Effect on Group Performance of Academic Staff Union of Adekunle Ajasin University Akungba Akoko, Ondo State
}

Gabriel Kola Olorunleke, Adeola Esther Adesida, Femi Seun Benjamin

To Link this Article: http://dx.doi.org/10.6007/IJARBSS/v10-i10/7946

DOI:10.6007/IJARBSS/v10-i10/7946

Received: 27 July 2020, Revised: 29 August 2020, Accepted: 19 September 2020

Published Online: 10 October 2020

In-Text Citation: (Olorunleke, Adesida, \& Benjamin, 2020)

To Cite this Article: Olorunleke, G. K., Adesida, A. E., \& Benjamin, F. S. (2020). Personality Traits and its Effect on Group Performance of Academic Staff Union of Adekunle Ajasin University Akungba Akoko, Ondo State. International Journal of Academic Research in Business and Social Sciences. 10(10), 405-421.

Copyright: (c) 2020 The Author(s)

Published by Human Resource Management Academic Research Society (www.hrmars.com)

This article is published under the Creative Commons Attribution (CC BY 4.0) license. Anyone may reproduce, distribute, translate and create derivative works of this article (for both commercial and non-commercial purposes), subject to full attribution to the original publication and authors. The full terms of this license may be seen at: $\underline{\text { http://creativecommons.org/licences/by/4.0/legalcode }}$

Vol. 10, No. 10, 2020, Pg. 405 - 421

http://hrmars.com/index.php/pages/detail/IJARBSS

JOURNAL HOMEPAGE

Full Terms \& Conditions of access and use can be found at http://hrmars.com/index.php/pages/detail/publication-ethics 


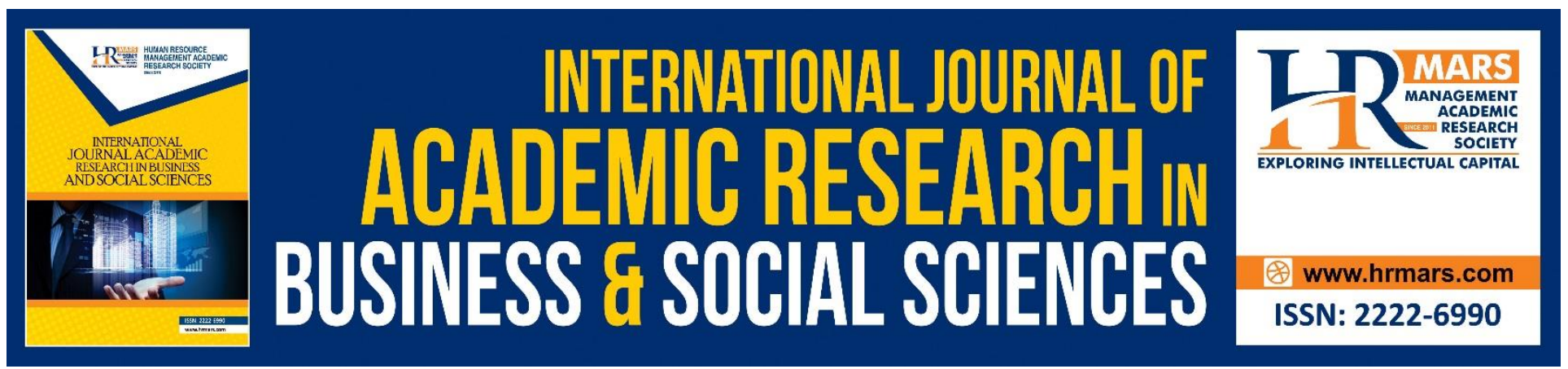

\title{
Personality Traits and its Effect on Group Performance of Academic Staff Union of Adekunle Ajasin University Akungba Akoko, Ondo State
}

\section{Gabriel Kola Olorunleke, Adeola Esther Adesida, Femi Seun Benjamin}

Department of Business Administration, Adekunle Ajasin University, Akungba-Akoko, Ondo State, Nigeria.

\begin{abstract}
Today, a growing number of organizations are turning to group as a way to develop and deploy their human capital in search of peak operational performance. However the success of a group depends on the attitude of the group members. Hence, this study assessed how personality traits affect group performance of Academic staff Union of Adekunle Ajasin University Akungba Akoko, Ondo state. A cross-sectional survey research design was used in carrying out this study and data were gathered from primary source. the population of the study consist of the total lecturers in Adekunle Ajasin University that belong to ASUU which is 431 staff while the sample size of the study was derived using Taro Yamane formula and this amounted to 207 staff. Purposive sampling technique was used in selecting the sample. The results revealed that the predictor variables (openness to experience, Neuroticism, Extraversions, Agreeableness and Conscientiousness) were individually statistically significant to group performance, and so the overall effect of personality trait on group performance was significant $(F=15.055, p<0.00)$. Based on the findings, it is recommended that organisation should give a reasonable attention to personality trait because it's the trait exhibited by individual that has an influence in the performance of the success of the group.
\end{abstract}

Keywords: Personality Trait, Group performance, Organisation, Commitment, ASUU

\section{Background to the Study}

Personality has received much attention from the research community in many contexts. In the last decades research on personality traits and its exploration in the context of work behaviour has been revitalized (Miller, 2015), especially in the domain of personality traits of leaders and followers.. Personality trait is relatively stable and enduring individual tendency of reacting emotionally or engaging in a behavior in a certain way (Abdul Waheed, Yang, \& Webber, 2017) personality was found to be a significant factor in the context of job satisfaction (Judge, Bono, \& Locke, 2000), job performance, (Anderson \& Viswesvaran, 1998) work attitudes (Judge, Heller, \& Mount, 2002), and 
INTERNATIONAL JOURNAL OF ACADEMIC RESEARCH IN BUSINESS AND SOCIAL SCIENCES Vol. 10, No. 10, 2020, E-ISSN: 2222-6990 @ 2020 HRMARS

behaviour (Barrick \& Mount, 1991). Miller (2015) opined that there is a strong connection between the personality trait of a group and the performance of an employee.

According to Kinicki, (2008), personality represents a stable set of characteristics that are responsible for a person's identity. The internal dimension or the primary dimensions of diversity are mostly outside our control but strongly influence our attitudes and our expectations and assumptions about others, thus influencing our behavior (Kinicki, 2008).Personality trait has a significant relationship with job performance and therefore positively influence work performance (Zimmerman, 2008)

In recent years, group performance has been a theme widely explored in the management domain. Various individual and team characteristics together with processes and management initiatives if appropriate may lead to positive team outcomes, and in turn to organizational success (Zimmerman, 2008). Group are seen as an ideal organizational entity because knowledge can be shared which improves (or might improve) performance. Today, group are an important cornerstone of organizations and most organizations rely on teams to fulfill their work and to obtain their goals. Thus, many of us already worked together for a longer period in a team and accomplished tasks in a work group. From our own experience, we all know that teamwork can be joyful and productive.

Today, a growing number of organizations are turning to group as a way to develop and deploy their human capital in search of peak operational performance (Salas, Stagi \& Burke, 2004). Group and coordinated teamwork are believed to provide significant business advantages including productivity, innovation, flexibility, job satisfaction, customer focus, and bottom-line business results (Katzenbach \& Smith, 1993).

The personality composition of groups of people working collaboratively on shared tasks has been shown to be an important predictor of performance (Sin'ead , Alan \& Hyowon ,2007). Therefore, this has led many organisations to focus on the trait of their employee.

The utilization of groups to accomplish the work once assigned to individuals has become one of the most prominent trends in organisations today. However the success of a group depends on the attitude on the group members ( Abdul , Jamhua, Jon, 2017). Studies by (Forrester \& Armen, 2017; Herath \& Faizal, 2017; Eyong, Emmanuel, David, Bassey \&Umoh, Augustus, 2014; Emecheta, Hart \& Ojiabo, 2016) has shown that personality trait has effect on the orgnaisational success and organizational commitment. However study by (Ethelbert, Richards \& Samson 2017; Ajayi , Shiyanbade , Ajayi Olaniyi, Olodude \& Olowoporoku ,2017) has indicated that personality trait has little or no effect to the performance of an individual, group or an organization, due to this controversy, this study examined the effect of personality on group performance of AAUA .

This studies provide answers to the following research questions

i. Which of the traits is the most predictive factor of job performance?

ii. What are the effects of personality traits on job performance?

The general objective of this study assessed how personality traits affect group performance of Academic staff Union of Adekunle Aajsin University Akungba Akoko, Ondo state. The specific objectives are to;

i. critically investigate the types of trait that are predictive factors of job performance in the selected tertiary Institution.

ii. empirically examine the link between personality traits and group performance in AAUA 
INTERNATIONAL JOURNAL OF ACADEMIC RESEARCH IN BUSINESS AND SOCIAL SCIENCES Vol. 10, No. 10, 2020, E-ISSN: 2222-6990 @ 2020 HRMARS

\section{Literature Review}

\section{Introduction}

In recruiting employees, competence based on relevant academic qualifications and previous experiences are often given credence by recruiters. An emerging paradigm is the influence of personality traits on employee performance. Divergent views, underpinned by several hypotheses have been reported on the relationship between personality traits and job performance. This chapter reviews the key literature and theories on the different personality traits; job performance and reported inter-relationships. At the end of the chapter, a summary on the current state of knowledge gaps are highlighted and the areas to which this study aims to contribute are also defined.

\section{Conceptual Definitions}

Kinicki, (2008), refers to personality as a stable set of characteristics that are responsible for a person's identity. The internal dimension or the primary dimensions of diversity are mostly outside our control but strongly influence our attitudes and our expectations and assumptions about others, thus influencing our behavior (Kinicki, 2008). Again, is a relatively enduring pattern of thinking, feeling and acting that characterize a person's response to his or her environment (Bratton et al, 2007). Personality looks at the individuality, where people differ significantly in the ways they routinely think, feel and act. Personality rests on the observation that people seem to behave somewhat consistently overtime and across different life situations for example, one would not be characterize a person having a shy personality if that person tended to be dominantly shy and retire only some of the time and on other occasions was frequently observed to be very sociable and outgoing. The study of personality involves examining factors within the people that causes them to behave consistently as they do. The determinants of personality are nature and nurture. Nature referring to the biological heritage and genetic makeup whilst Nurture is the life experiences one has gone through. Twins studies indicate that identical twins that grow up together in the same family have the same permissiveness or strict and similar life experiences. If the twins have similar personality, it is impossible to identify the source of similarity because they have not only the same genetic makeup but also similar experiences including strictness or permissiveness of a child's parent, the number of other children in the family, demands from parents and teachers and culture (Kinicki, 2008).It is perceived that personality is stable over periods of time because half of the variations is inherited from parents and is also likely to change as one environment changes. Personality is an important difference that managers and organizational members need to take into account because realizing for example that an employee complains a lot because of his or personality will help managers and colleagues deal this type of employee's job performance (Kinicki, 2008).

\section{Dimension of Personality Traits}

Personality traits are the structures and propensities that explain individual's characteristic patterns of thought, emotion and behavior and recurring regularities or trends in him/her trait (Colquitt, Jason, et al. 2011) People's personality explains their enduring traits and characteristics in relation to emotions, motivations, interpersonal interactions and attitudes which differ from their abilities. It endures and predicts people's attitudes towards situations and other people but is transient. It encompasses a person's relative stable feelings, thoughts, behavioral patterns; form unique personality that differentiates people from others but proper understanding of such personality provide clue about how he/she is likely to act and feel in various situations. Studies show that 
INTERNATIONAL JOURNAL OF ACADEMIC RESEARCH IN BUSINESS AND SOCIAL SCIENCES Vol. 10, No. 10, 2020, E-ISSN: 2222-6990 @ 2020 HRMARS

personalities influence the environments where people reside and play vital role in choosing condition within which people attempt to stay (Chen . 2004). In this study personality is measured through the big five personality model. The "Five Factor Theory" or the so called "Big Five Personality Model" has been developed by Norman (NormanWarren,1963)

\section{Openness to experience}

Openness to experience is how open minded a person is and people possessing this trait are highly imaginative, creative intellect, sensitive to inner thoughts have the capability to analyze matters differently, exhibit intellectual curiosity, art, knowledge, independent-minded, have a preference for novelty and variety; curious to know hidden things and deductive from different angles (Cattell , Alan \& Mead, 2008). It expresses an individual's tendency to be open to different beliefs, viewpoints, and experiences. (Goldberg LR.1990). Further, Openness to experience which refers to personality attributes as creative, sensitive, curious, cultivated and independent minded

\section{Conscientiousness}

Conscientiousness measures how organized, thoughtful and forward-thinking an individual can be. Conscientious employees are cautious, orderly, dependable, graceful, show self-discipline, acts dutifully and responsible. People with conscientious personality are highly influenced by their career success in the organization, tend to be very careful about their future planning, cautious about their surroundings, compact and fully scheduled, tend to be self-managed, prefer to be predictable and try to be risk free (Burch, Neil, 2008). Conscientiousness includes some personality traits like being analytical, responsible, prudent, patient and working hard and is about controlling, organizing and managing one's instincts .Further, conscientiousness which refers to the degree to which an individual is responsible, disciplined, organized and goal achiever [Abdullah, lqra, Rozeyta , Yahya , 2013).

\section{Extraversions}

Extraversion represents a personality trait showing people to be energetic, high in sociability, assertiveness and positively emotional. People high in extroversion are talkative, arguing for their opinions, interacting with every one so frankly and seeks excitement in every bit of life (Burch, Neil , 2008). This quality of personality makes people more social with an out-going personality, always ready to interact with people in the society [Barrick, .1998$)$

\section{Agreeableness}

Agreeableness reflects individual differences related to collaboration and social compliance. Agreeable individuals are respectful, friendly, helpful and generous and get along with others easily as they have an optimistic view of human nature (Goldberg .1990).Agreeableness personality trait showed people as being very accommodating, trustful, generous, tolerant, and compassionate. People high in this trait are always helping, ready to resolve issues by creating a win-win situation due to their flexible attitude and usually highly sociable, friendly and generous in negotiations in a friendly environment to keep balance with opponent's concerns have the propensity to attain cooperation and social harmony, helping others is their inbuilt feature and for that reason they believe others are also honest and trustworthy . 
INTERNATIONAL JOURNAL OF ACADEMIC RESEARCH IN BUSINESS AND SOCIAL SCIENCES Vol. 10, No. 10, 2020, E-ISSN: 2222-6990 @ 2020 HRMARS

\section{Neuroticism}

Neuroticism personality is characterized by fearfulness, anxiety, worry, envy, frustration, emotionally-unstable, jealousy and loneliness. People high in neuroticism exhibit frustrations, anger, depression, stress and self-blame and such individuals are associated with pessimism, over react over mistakes and faults made by them [Howard \& Jane,1995]. They are easily trapped by stress and tend to be emotional and anxious [Saucier \& Orthogonal 2002].Almost always hopeless and frustrated when exhibiting feelings and behaviors.

\section{Group Performance}

For the present model, team performance is conceptualized as a global construct having three dimension; team effort, team performance effectiveness, and commitment. This approach is consistent with prior literature and empirical evidence supports the proposition that these outcomes are influenced by personality composition Fisher et. al. (2012), for example, showed that agreeableness was positively related to similarity in team work conceptualization, coordination, and team performance.

\section{Personality Traits Theories}

\section{Sigmund Freud's Psychoanalytic Theory}

Psychoanalysts believe man's behaviour is triggered mostly by powerful hidden forces within the personality. These forces are shaped by childhood experiences and they play an important role in energizing and directing our everyday behaviour. Sigmund Freud, an Australian physician was the originator of this theory in the early nineties He says much of people's everyday behaviour is motivated by unconscious forces about which they know little. In order to fully understand personality then one need to illuminate and expose what is in the unconscious. According to Freud's model of personality, there are three major components: the id, the ego and the superego, which although are separate components, interact within the individual. The id, which is the raw, untamed, unorganized, uncultured and inherited part of personality whose function is to reduce the tension created by biological drives such as hunger, sex, aggressiveness and irrational impulses. It operates according to the pleasure principle which goal is the immediate reduction of tension and maximization of pleasure. However harsh realities of life prevent the satisfaction of the demands of the pleasure principle in most cases by presenting constraints. The ego acts as buffer and helps cushion the effects of reality. The ego operates according to the reality principle in which instinctual energy is retrained in order to maintain the safety of the individual and help to integrate him into the society. The ego makes decisions controls actions and allows thinking and problem solving of a higher order than the id is capable of. The superego acts the final component, which represents rights and wrongs of society as handed down by one's parents, teachers and other important figures. It becomes part of personality when children learn rights from wrongs and continue to develop as people in the society in which they live begin to incorporate their own standards into them. These are the components of adult personality. Whenever the demands of the id or the super ego threaten to overwhelm the ego, anxiety is the result. Ego defense mechanisms such as regression, denial, repression etc. are therefore used to reduce to reduce anxiety by distorting either thoughts or reality. Although Freud's conception faced a lot of criticisms due to dearth of scientific evidence to support it, nevertheless it had gained a lot of impact in the field of psychology. 
INTERNATIONAL JOURNAL OF ACADEMIC RESEARCH IN BUSINESS AND SOCIAL SCIENCES Vol. 10, No. 10, 2020, E-ISSN: 2222-6990 @ 2020 HRMARS

\section{Empirical Review}

Ethelbert . Njoku, Richards and Samson Okwuchukwu (2016) investigated five personality dimensions -openness to experience, conscientiousness, extraversion, agreeableness, and neuroticism as predictors of organizational commitment among selected employees in Enugu. Using convenience sampling technique, 200 employees were selected from four public and private sector employees in Enugu metropolis. The participants comprised of 115 males and 85 females with ages ranging from $22-50$ years and a mean age of 36.00 years. Participants were administered with the Big Five Personality Inventory by John and Srivastava (1999) and the Organisational Commitment Scale by Buchanan (1974). Five hypotheses werepostulated and tested using cross sectional survey design and multiple regression analyses. Result showed that only openness to experience significantly predicted employees' organisational commitment. Conscientiousness, extraversion, agreeableness and neuroticism were not significant predictors of employees' organisational commitment. Based on the findings, it is recommended that employers apply personality tests in assessing potential employees

Emecheta, Awa and Ukoha (2016) investigated five personality dimensions -openness to experience, conscientiousness, extraversion, agreeableness, and neuroticism as predictors of organisational commitment among selected employees in Enugu. Using convenience sampling technique, 200 employees were selected from four public and private sector employees in Enugu metropolis. The participants comprised of 115 males and 85 females with ages ranging from $22-50$ years and a mean age of 36.00 years. Participants were administered with the Big Five Personality Inventory by John and Srivastava (1999) and the Organizational Commitment Scale by Buchanan (1974). Five hypotheses were postulated and tested using cross sectional survey design and multiple regression analyses. Result showed that only openness to experience significantly predicted employees' organizational commitment. Conscientiousness, extraversion, agreeableness and neuroticism were not significant predictors of employees' organizational commitment. Based on the findings, it is recommended that employers apply personality tests in assessing potential employees Eyong, Emmanuel ,David and Umoh, Augustus (2014) investigated the influence of personality traits on academy achievements of secondary school students in Cross River State. Two research questions and hypotheses were tested at .05 levels of significance to guide the conduct of the study. The research design used was casual-comparative or ex-post facto. The population of the study consisted of $13,838 \mathrm{SSI}$ students in all 239 public secondary schools throughout Cross Rivers State. A total of 7 LGAs were randomly drawn out of 23 . Then 20 schools were randomly selected, from which a sample of $8530 \mathrm{SSI}$ students was finally drawn. The instrument adapted for the study was the 44-item standardized questionnaire known as the big five personality model by Robert McCrae and Paul Costa (1999). This was validated by expert in the field of measurement and evaluation; the reliability was established using the test re-test method and the reliability coefficient was calculated using Pearson moment correlation coefficient( $r$ ) and the reliability indices obtained were, 0.68 , and 0.62 respectively for conscientiousness and agreeableness. The data collected were analyzed using the mean $(x)$ and standard deviation (SD) to answer the research question. The independent sample ttest was used to test the hypothesis in order to determine whether there is a significance difference between the means two independent groups being compared for each trait. A significant difference was found between the achievements of students with high level of conscientiousness and agreeableness, and those with low levels of the traits.

Ajayi , Shiyanbade, Ajayi, Olodude And Olowoporoku (2017) examined the influence of personality traits, and work commitment on Job performance of public secondary school teachers in Oyo South 
Senatorial District of Oyo State, Nigeria. It also assessed the level of job performance of public secondary school teachers and investigated the combined influence of personality traits and work commitment on Job performance of these teachers with a view to improving their job performance level in the senatorial district and Oyo State in general. The study adopted descriptive survey research design. The sample for this study consisted of 15 principals,75 HODs and 300 class teachers in the senatorial district. Five local government councils were selected from nine local government councils in Oyo South senatorial district using simple random sampling technique. Frequency counts, simple percentages, chi-square and one-way ANOVA statistics were employed to analyze the data. The hypotheses were tested at the 0.05 level of significance. The results revealed that $15.7 \%, 67.9 \%$ and $16.4 \%$ of public secondary school teachers in the senatorial district demonstrated low, moderate and high levels of job performance respectively. Also, $72.1 \%$ of the teachers had a moderate level of work commitment, $1.7 \%$ had a high level while $11.7 \%$ had a low level of work commitment. The results further showed that there was no significant influence of personality traits on teacher's job performance $(X 2=6.730, d f=8, p=566)$. It was established that there was significant influence of personality traits on the job performance of teachers $(X 2=49.942, \mathrm{df}=4, \mathrm{p}=.00)$. Moreover, the result showed that the combination of personality traits and work commitment will significantly influence the job performance of the teachers $(F=541.158, P>0.05)$. The study concluded that work commitment had the greater influence on the job performance than personality traits.

\section{Conceptual Frame work}

The relationship between independent and dependent variables is show in this framework. Personality trait acts as the independent variable and it will be measured using : Neuroticism, Agreeableness, Extraversions, Conscientiousness and Openness to experience. The Group performance will be act as the dependent variable and it will be measured using: Commitment. This is diagrammatically show in fig 2.1

\section{Independents Variable \\ Personality Trait}

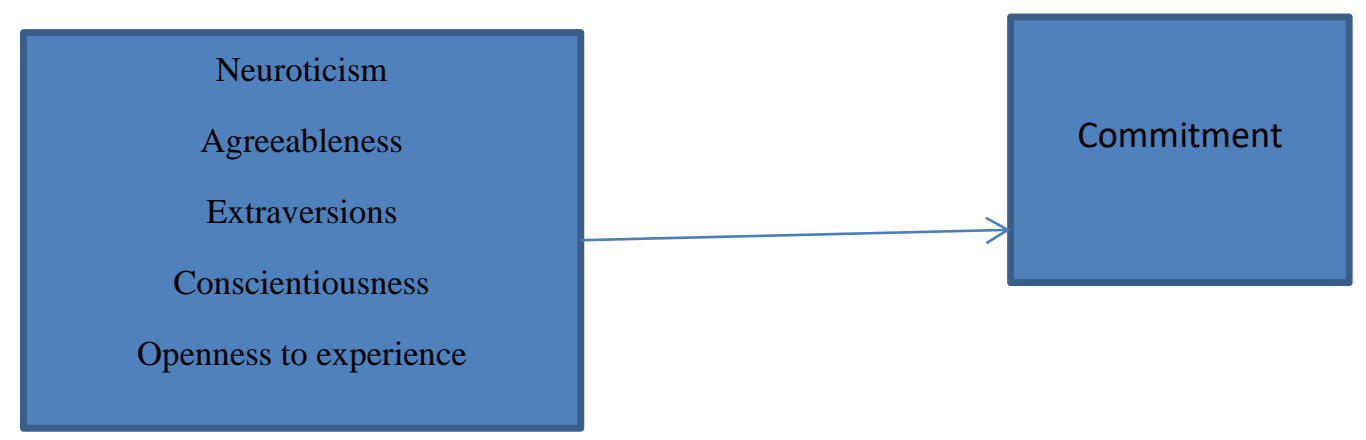

\section{Dependent Variable} Group Performance

\section{Source: Researchers computation}

\section{Methodology}

This chapter addressed the methodology adopted for the analysis of the effect of personality traits on group performance of ASUU AAUA. It was organized as follows: Research Design, Sources of data, Sample size and Sampling Technique, Research Instruments, Validity of Research Instrument, administration of the research instrument, model specification, measurement of variables, and data analysis techniques. 
INTERNATIONAL JOURNAL OF ACADEMIC RESEARCH IN BUSINESS AND SOCIAL SCIENCES Vol. 10 , No. 10, 2020, E-ISSN: 2222-6990 @ 2020 HRMARS

A cross-sectional survey research design was used in carrying out this study. A cross-sectional survey offered the opportunity to collect data across different sectors per time period.

In adopting any method in Research study, it is imperative to put into consideration the approach that yield the most productive result relevant to the problems at hand. In regard, data for this study were gathered from primary source.

the population of the study consist of the total lecturers in Adekunle Ajasin University that belong to ASUU which are 431 staff, while the sample size of the study was derived using Taro Yamane formula and this amounted to 207 staff.

$\mathrm{S}=\frac{N}{1+N\left(x^{2}\right)}$

The sample size of this study was derived using Taro Yamane formula

The variable Nrepresents the population of the study which is 431, Margin of error is donated by " $\mathrm{e}$ " which was put at 0.05 .while the $\mathbf{S}$ is the unknown sample size.

$$
\begin{gathered}
\frac{431}{1+431\left(0.05^{2}\right)} \\
\frac{431}{1+431(0.0025)} \\
\frac{431}{1+\frac{1.0775}{2.0775}}
\end{gathered}
$$

207 ASUU staff

Purposive sampling technique was used in selecting the sample. These respondents were in the positions to supply the type of information needed for this study. The main instrument of this study was structured questionnaire designed to collect information from the respondents. The questionnaire consists of closed ended questions specifically designed to achieve the stated objectives of the study and to analyze the research hypothesis. Structured questionnaire administered to each respondents were used to obtain qualitative information about the study

The questionnaires adopted the check list on personality traits which had been adopted by previous researchers and authors (Colquitt, Jason, et al. 2011). The instrument (Questionnaire) was presented to my supervisor and experts for vetting and the reliability of the instrument using Cronbach"sAlpha. Validity: A measuring instrument is valid when it measures what it is design to measured. The content validity was used for this study because it adequately covers the scope implied by the study. The Hypothesis of the study state that; There is no significant relationship between personality trait and group performance

\section{Data Presentation, Analysis and Interpretation}

This chapter presents the data obtained for the study in the form of tables to which references were made. The study considered the analysis of data generated from the research study in relation to the responses obtained through the administration of questionnaire. 
INTERNATIONAL JOURNAL OF ACADEMIC RESEARCH IN BUSINESS AND SOCIAL SCIENCES Vol. 10, No. 10, 2020, E-ISSN: 2222-6990 @ 2020 HRMARS

Trait of Group Job Peformance

Table 4.1 The traits that is the most predictive factor of job performance

\begin{tabular}{|c|c|c|c|c|c|c|c|c|}
\hline \multirow{2}{*}{$\begin{array}{l}\text { Openness to } \\
\text { Experience }\end{array}$} & \multicolumn{5}{|c|}{ Frequencies } & \multirow{2}{*}{$\begin{array}{l}\text { Mea } \\
\mathrm{n}\end{array}$} & \multirow[t]{2}{*}{ Median } & \multirow[t]{2}{*}{ St. Dev } \\
\hline & $\begin{array}{l}\text { Strongly } \\
\text { Agreed }\end{array}$ & Agreed & Neutral & Disagreed & $\begin{array}{l}\text { Strongly } \\
\text { Disagreed }\end{array}$ & & & \\
\hline $\begin{array}{l}\text { Someone who is } \\
\text { original and create new } \\
\text { idea influence job } \\
\text { performance }\end{array}$ & $92(47.4 \%)$ & $\begin{array}{l}49 \\
(25.4 \%)\end{array}$ & $20(10.4 \%)$ & $16(8.3 \%)$ & $16(18.3 \%)$ & 2.04 & 2.00 & 1290 \\
\hline $\begin{array}{l}\text { People with an active } \\
\text { imagination assist the } \\
\text { group success }\end{array}$ & $68(35.2 \%)$ & $79(40.9 \%)$ & $22(11.4 \%)$ & $24(12.4 \%)$ & $0(0 \%)$ & 2.01 & 2.00 & .984 \\
\hline $\begin{array}{r}\text { Sophisticated art, } \\
\text { music, or literature } \\
\text { helps others to } \\
\text { improve their ability to } \\
\text { performed better }\end{array}$ & $73(37.8 \%)$ & $44(22.8 \%)$ & $12(6.2 \%)$ & $44(22.8 \%)$ & $20(10.4 \%)$ & 2.45 & 2.00 & 1.447 \\
\hline $\begin{array}{r}\text { A deep thinker in a } \\
\text { group makes a group } \\
\text { to be successful }\end{array}$ & $165(85.5 \%$ & $28(14.5 \%)$ & $0(0 \%)$ & $0(0 \%)$ & $0(0 \%)$ & 1.15 & 1.00 & .3 .53 \\
\hline \multicolumn{9}{|l|}{ Conscientiousness } \\
\hline $\begin{array}{l}\text { Someone that } \\
\text { perseveres until the } \\
\text { task is finished lead to } \\
\text { success }\end{array}$ & $39(20.2 \%)$ & $68(35.2 \%)$ & $39(20.2 \%)$ & $31(16.1 \%)$ & $16(8.3 \%)$ & 2.57 & 2.00 & 1.215 \\
\hline $\begin{array}{l}\text { full of energy individual } \\
\text { influence the group } \\
\text { performance }\end{array}$ & $\begin{array}{l}92(47.7 .0 \\
\%)\end{array}$ & $49(25.4 \%)$ & $20(10.4 \%)$ & $16(8.3 \%)$ & $16(8.3 \%)$ & 2.04 & 2.00 & 1.290 \\
\hline $\begin{array}{r}\text { People that do things } \\
\text { efficiently create group } \\
\text { success }\end{array}$ & $36(18.7 \%)$ & $63(32.6 \%$ & $24(12.4 \%)$ & $27(14.0 \%)$ & $43(22.3 \%)$ & 2.89 & 2.00 & 1.450 \\
\hline $\begin{array}{r}\text { He that makes plans } \\
\text { and follows through } \\
\text { with affect group } \\
\text { success }\end{array}$ & $68(35.2 \%)$ & $43(22.3 \%)$ & $10(5.2 \%)$ & $16(8.3 \%)$ & $56(29.0 \%)$ & 2.74 & 2.00 & 1.679 \\
\hline \multicolumn{9}{|l|}{ Extraversion } \\
\hline $\begin{array}{l}\text { Someone who is } \\
\text { outgoing and sociable } \\
\text { influence others }\end{array}$ & $92(47.7 \%)$ & $49(25.4 \%$ & $20(10.4 \%)$ & $16(8.3 \%)$ & $16(8.3 \%)$ & 2.04 & 2.00 & 1.290 \\
\hline $\begin{array}{l}\text { People that generates } \\
\text { a lot of enthusiasm are } \\
\text { successful people }\end{array}$ & $36(18.7 \%)$ & $63(32.6 \%$ & $24(12.4 \%)$ & $27(14.0 \%)$ & $43(22.3 \%)$ & 2.89 & 2.00 & 1.450 \\
\hline $\begin{array}{l}\text { People that likes to talk } \\
\text { a lot help others to }\end{array}$ & $\begin{array}{l}68(35.2 \% \\
)\end{array}$ & $43(22.5 \%)$ & $10(5.2 \%)$ & $16(8.3 \%)$ & $56(29.0 \%)$ & 2.74 & 2.00 & 1.679 \\
\hline
\end{tabular}


INTERNATIONAL JOURNAL OF ACADEMIC RESEARCH IN BUSINESS AND SOCIAL SCIENCES Vol. 10, No. 10, 2020, E-ISSN: 2222-6990 @ 2020 HRMARS

\begin{tabular}{|c|c|c|c|c|c|c|c|c|}
\hline $\begin{array}{l}\text { communicate their } \\
\text { mind } \\
\text { Someone who do not } \\
\text { easily associate with } \\
\text { people reduced the } \\
\text { moral of group effort }\end{array}$ & $32(16.6 \%)$ & $76(39.4 \%)$ & $37(19.2 \%)$ & $48(24.9 \%)$ & $0(0 \%)$ & 2.52 & 2.00 & 1.041 \\
\hline \multicolumn{9}{|l|}{ Agreeableness } \\
\hline $\begin{array}{l}\text { Individual that likes to } \\
\text { cooperate with others } \\
\text { motivate others }\end{array}$ & $68(35.2 \%)$ & $75(38.9 \%)$ & $18(9.3 \%)$ & $32(16.6 \%)$ & $0(0 \%)$ & 2.07 & 2.00 & .1 .053 \\
\hline $\begin{array}{l}\text { Someone who has a } \\
\text { forgiving nature has } \\
\text { chances of success }\end{array}$ & $44(22.8 \%)$ & $67(34.7 \%)$ & $35(18.1 \%)$ & $31(16.1 \%)$ & $16(8.3 \%)$ & 2.52 & 2.00 & 1.238 \\
\hline $\begin{array}{l}\text { Someone who is } \\
\text { helpful and unselfish } \\
\text { with others are } \\
\text { successful one. }\end{array}$ & $91(47.2 \%)$ & $54(28.0 \%)$ & $16(8.3 \%)$ & $16(8.3 \%)$ & $16(8.3 \%)$ & 2.03 & 2.00 & 1.281 \\
\hline $\begin{array}{l}\text { People that tends to } \\
\text { accept others' view } \\
\text { accept their support }\end{array}$ & $60(31.1 \%)$ & $81(42.2 \%)$ & $24(12.4 \%)$ & $8(4.1 \%)$ & $20(10.4 \%)$ & 2.21 & 2.00 & 1.244 \\
\hline Neuroticism & $58(30.1 \%)$ & $18(9.3 \%$ & & & & & & \\
\hline $\begin{array}{l}\text { Someone who is } \\
\text { worries a lot has ability } \\
\text { to affect work }\end{array}$ & $93(48.2 \%)$ & $62(32.1 \%)$ & $16(8.3 \%)$ & $58(30.1 \%)$ & $43(22.3 \%)$ & 3.05 & 4.00 & 1.580 \\
\hline $\begin{array}{l}\text { Ability to easily change } \\
\text { mood leads to job } \\
\text { success }\end{array}$ & $\begin{array}{l}102(52.8 \% \\
)\end{array}$ & $41(21.2 \%)$ & $8(4.1 \%)$ & $30(15.5 \%)$ & $0(0 \%)$ & 1.87 & 2.00 & 1.065 \\
\hline $\begin{array}{l}\text { Ability to elicit negative } \\
\text { emotions in a person } \\
\text { improve performance }\end{array}$ & $138(71.5 \%$ & $39(20.2 \%)$ & $4(2.1 \%)$ & $11(5.7 \%)$ & $35(18.1 \%)$ & 2.15 & 1.00 & 1.549 \\
\hline $\begin{array}{r}\text { your emotional } \\
\text { stability affect your } \\
\text { performance }\end{array}$ & I & & $0(0 \%)$ & $0(0 \%)$ & $0(0 \%)$ & 1.53 & 1.00 & 1.118 \\
\hline
\end{tabular}

Field Survey, 2019

The analysis in Table 4.2. showed the analysis of the traits that is the most predictive factor of job performance. The results of the analysis indicated that Someone who is original and create new idea 
INTERNATIONAL JOURNAL OF ACADEMIC RESEARCH IN BUSINESS AND SOCIAL SCIENCES Vol. 10, No. 10, 2020, E-ISSN: 2222-6990 @ 2020 HRMARS

influence job performance. This was confirmed by a mean value of 2.04 on a scale of 5.0 indicating that I am aware of my emotions as I experience them which is (40.8\%).

Also, the results revealed that People with an active imagination assist the group success. This was confirmed by a mean value of 2.01 on a scale of 5.0 indicating that I know why my emotions change (40.2\%).

In addition, Sophisticated art, music, or literature helps others to improve their ability to performed better. This was confirmed by a mean value of 2.45 on a scale of 5.0 indicating that I am confident to express my emotions in a perfect way with (49.0\%).

Furthermore, A deep thinker in a group makes a group to be successful. This was confirmed by a mean value of 1.15 on a scale of 5.0 indicating that I have control over my emotions with (23.0\%).

Furthermore, Someone that perseveres until the task is finished lead to success. This was confirmed by a mean value of 2.57 on a scale of 5.0 indicating that I have control over my emotions with (51.4\%). Also, full of energy individual influence the group performance. This was confirmed by a mean value of 2.04 on a scale of 5.0 indicating that I do not lose control in worst situations $(40.8 \%)$.

The results of the analysis also indicated that People that do things efficiently create group success . This was confirmed by a mean value of 2.89 on a scale of 5.0 indicating that I can consciously alter my frame of mind or mood which is $(57.8 \%)$.

In addition, He that makes plans and follows through with affect group success. This was confirmed by a mean value of 2.74 on a scale of 5.0 indicating that While making decisions, I endeavor to put others into consideration with (54.8\%).

Also, the results revealed that Someone who is outgoing and sociable influence others. This was confirmed by a mean value of 2.04 on a scale of 5.0 indicating that I have a good understanding of the emotions people around me (40.8\%).

In addition, People that generates a lot of enthusiasm are successful people. This was confirmed by a mean value of 2.89 on a scale of 5.0 indicating that While making decisions, I endeavor to put others into consideration with (57.8\%).

Furthermore, People that likes to talk a lot help others to communicate their mind. This was confirmed by a mean value of 2.74 on a scale of 5.0 indicating that I can sometimes see things from others' point of view with (54.8\%).

In addition, Someone who do not easily associate with people reduced the moral of group effort. This was confirmed by a mean value of 2.52 on a scale of 5.0 indicating that While making decisions, I endeavor to put others into consideration with (50.4\%).

Also, Individual that likes to cooperate with others motivate others. This was confirmed by a mean value of 2.52 on a scale of 5.0 indicating that Awareness of others' emotions will enhance my relationship with them $(50.4 \%)$.

In addition, I am good at adapting and mixing with a variety of people. This was confirmed by a mean value of 2.03 on a scale of 5.0 indicating that I am good at adapting and mixing with a variety of people with (40.6\%).

Furthermore, Someone who has a forgiving nature has chances of success. This was confirmed by a mean value of 2.21 on a scale of 5.0 indicating that Encouraging employees to share their private problems with management brings them closer to the organization with (44.2\%)

Also, Someone who is helpful and unselfish with others are successful one. . This was confirmed by a mean value of 3.05 on a scale of 5.0 indicating that Awareness of others' emotions will enhance my relationship with them (61.0\%). 
INTERNATIONAL JOURNAL OF ACADEMIC RESEARCH IN BUSINESS AND SOCIAL SCIENCES Vol. 10, No. 10, 2020, E-ISSN: 2222-6990 @ 2020 HRMARS

In addition, People that tends to accept others' view accept their support. This was confirmed by a mean value of 1.87 on a scale of 5.0 indicating that I am good at adapting and mixing with a variety of people with (37.4\%).

In addition, Someone who is worries a lot has ability to affect work. This was confirmed by a mean value of 2.15 on a scale of 5.0 indicating that I am good at adapting and mixing with a variety of people with (43.0\%).

Furthermore, Ability to easily change mood leads to job success. This was confirmed by a mean value of 1.53 on a scale of 5.0 indicating that Encouraging employees to share their private problems with management brings them closer to the organization with (30.6\%)

Also, Ability to elicit negative emotions in a person improves performance. This was confirmed by a mean value of 1.87 on a scale of 5.0 indicating that Awareness of others' emotions will enhance my relationship with them (37.4\%).

In addition, your emotional stability affects your performance. This was confirmed by a mean value of 2.05 on a scale of 5.0 indicating that I am good at adapting and mixing with a variety of people with (41.0\%).

Table 4.2 Effect of personality trait and group performance

\begin{tabular}{|c|c|c|c|c|c|c|c|}
\hline \multirow[t]{2}{*}{ Model } & \multicolumn{2}{|c|}{$\begin{array}{r}\text { Unstandardized } \\
\text { coefficients }\end{array}$} & \multirow{2}{*}{$\begin{array}{r}\text { Standardiz } \\
\text { ed } \\
\text { coefficients } \\
\text { Beta }\end{array}$} & \multirow[t]{2}{*}{$\mathrm{T}$} & \multirow[t]{2}{*}{ Sign } & \multicolumn{2}{|c|}{$\begin{array}{r}\text { Collinearity } \\
\text { statistics }\end{array}$} \\
\hline & $B$ & Std Error & & & & $\begin{array}{r}\text { Toleran } \\
\text { ce }\end{array}$ & VIF \\
\hline Constant & 4.663 & .973 & & 4.791 & .000 & & \\
\hline NEU & .068 & .088 & .087 & 2.775 & .004 & .328 & 3.049 \\
\hline OTE & .236 & .089 & .319 & 2.663 & .000 & .266 & 3.759 \\
\hline EX & .213 & .068 & .276 & 3.132 & .002 & .492 & 2.033 \\
\hline AG & .184 & .103 & .260 & 3.792 & .045 & .181 & 5.512 \\
\hline $\mathrm{CO}$ & .127 & .069 & .170 & 2.835 & .000 & .446 & 2.240 \\
\hline \multicolumn{8}{|c|}{ Model Statistics } \\
\hline & & & & \multicolumn{3}{|c|}{$\mathrm{R}$} & .536 \\
\hline & & & & \multicolumn{3}{|c|}{$\mathrm{R}^{2}$} & .287 \\
\hline & & & & \multicolumn{3}{|c|}{ Adjusted $\mathrm{R}^{2}$} & .268 \\
\hline & & & & \multicolumn{3}{|c|}{ S. E of estimate } & 1.66777 \\
\hline & & & & \multicolumn{3}{|c|}{ F- stat } & 15.055 \\
\hline & & & & \multicolumn{3}{|c|}{ Sig (F stat) } & 0.000 \\
\hline & & & & & \multicolumn{2}{|c|}{ DW stat } & .855 \\
\hline
\end{tabular}

Source: Field Survey, 2019.

a.Dependent variable COM

Predictors: (Constant), NEU, OTE, EX, AG, CO. 
INTERNATIONAL JOURNAL OF ACADEMIC RESEARCH IN BUSINESS AND SOCIAL SCIENCES

Vol. 10, No. 10, 2020, E-ISSN: 2222-6990 @ 2020 HRMARS

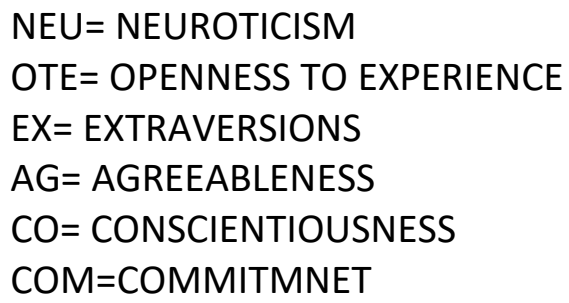

In addition to the descriptive analysis shown in Table 4.2 an inferential analysis (regression analysis) was also used to test the hypothesis: There is no significant relationship between personality trait and group performance. The analysis in Table 4.3 indicates the influence of personality trait on group performance. The results revealed that the predictor variables (openness to experience, Neuroticism, Extraversions, Agreeableness and Conscientiousness) were individually statistically significant to group performance. Neuroticism explained $68.0 \%$ of the variance in the performance AAUA, openness to experience explained $23.6 \%$ of the variance in the performance of AAUA, Extraversions explained $21.3 \%$, Agreeableness explained $18.4 \%$ while Conscientiousness explained $12.7 \%$ of the variance in the group performance. However, the overall effect of personality trait on group performance was significant $(F=15.055, p<0.00)$.

\section{Discussion of Findings}

The inferential analysis (regression analysis) was used to test the hypothesis:There is no significant relationship between personality trait and group performance. The analysis in Table 4.2 indicates the influence of personality trait on group performance. The results revealed that the predictor variables (openness to experience, Neuroticism, Extraversions, Agreeableness and Conscientiousness) were individually statistically significant to group performance. Neuroticism explained $68.0 \%$ of the variance in the performance AAUA, openness to experience explained $23.6 \%$ of the variance in the performance of AAUA, Extraversions explained 21.3\%, Agreeableness explained 18.4\% while Conscientiousness explained $12.7 \%$ of the variance in the group performance. However, the overall effect of personality trait on group performance was significant $(F=15.055, p<0.00)$.

\section{Policy Implications of Research Findings}

The outcome of this study will be of great benefit to institution in order to foster more group cohesion among members. Organisation that observe and try to know the personality trait of his member will have a positive result among the group

\section{Summary and Conclusion \\ Summary}

This study examined the effect of personality trait on group performance of Adekunle Ajasin University ASUU. To achieve this, one hundred and ninety eight (198) copies of a set of structural questionnaire were administered to respondents using Taro Yamane formula. After a systematic analysis of the data in accordance with the research objectives and hypothesis, this study revealed that personality trait contributed positively and significantly to the group performance of ASUU.

this study investigated the effect of personality trait on the group performance measured by. The results revealed that personality trait had significant effect on group performance. Using regression analysis, the results revealed that there was significant relationship among the personality 
INTERNATIONAL JOURNAL OF ACADEMIC RESEARCH IN BUSINESS AND SOCIAL SCIENCES Vol. 10, No. 10, 2020, E-ISSN: 2222-6990 @ 2020 HRMARS

triat dimensions and group performance $(F=15.055 ; p<0.005)$ Thus, personality trait had significant effect on group performance in the AAUA (ASSU).

\section{Conclusion}

The study revealed that personality trait which are measured with Neuroticism, agreeableness, extraversions, conscientiousness and openness to experience will improved the performance of group significantly in in agreement with the work of William, Forrester \& Armen ,2017; Herath \& Faizal , 2017; Eyong, Emmanuel , David, Bassey \&Umoh, Augustus , 2014; Emecheta , Hart \& Ojiabo , 2016 who opined from the findings of their studies that there was positive influence of personality trait on performance of group.

The study contributed to knowledge by giving insight to ASUU executive to always considered the trait of their group members so as to enhance their performance

In Nigeria today, the rise of strike actions has been of high side (Senator Ngige, 2019). The last strike action between ASUU and Federal Government shows that there are issues between the Staff of ASUU, because most Institution fails to join the strike, but AAUA join the last strike, despite the fact that AAUA ASUU joined the strike, Some member of the staff did not join the strike, which make the strike not to be effective. The findings of this study are expected to be of importance to ASUU executive by enlighten them on the ways to appreciate and understand the personality traits of every individual member.

Personality can be seen as the character of every individual that make the person to be whom he/she is.it is the identity of individual that show who he/she is.

The study supported Sigmund Freud's Psychoanalytic Theory of personality, leaders should know that the behaviour of every individual can change at any time, and the motivating factors that leads to change or that lead to the change must be quickly address by leaders.

\section{Recommendation}

The study recommends that organisation should give a reasonable attention to personality trait because it's the trait exhibited by individual has an influence in the performance of the success of a group.

\section{References}

Abdullah, I., Omar, R., \& Rashid, Y. (2013). Effect of Personality on Organizational Commitment and Employees' Performance: Empirical Evidence from Banking Sector of Pakistan, Middle-East Journal of Scientific Research 18 (6), 759-766.

Ajayi, A., Shiyanbade, B. W., Ajayi, O. A., Olodude, D. O., \& Olowoporoku, A. J.(2017) Influence of Personality Traits and Work Commitment on Job Performance of Public Secondary School Teachers in Oyo South Senatorial District of Oyo State, Nigeria. International journal of Rural Development, Environment and Health Research(IJREH) Vol-1, Issue-1, May-Jun, 2017

Anderson, G., \& Viswesvaran, C. (1998,). An update of the validity of personality scales in personnel selection: A meta-analysis of studies published after 1992. Poster presented at the thirteenth annual conference of the Society for Industrial and Organizational Psychology, Dallas, TX

Barrick, R. M., Stewart, G. L., Neubert, M. J., \& Mount, M. K. (1998). Relating member ability and personality to work-team processes and team effectiveness. Journal of Applied Psychology, $83,43-51$. 
INTERNATIONAL JOURNAL OF ACADEMIC RESEARCH IN BUSINESS AND SOCIAL SCIENCES Vol. 10, No. 10, 2020, E-ISSN: 2222-6990 @ 2020 HRMARS

Barrick, R. M., \& Mount, M. K. (1991). The Big Five personality dimensions and job performance: A meta-analysis. Personal Psychology, 44, 1-26.

Burch, G. S. J., \& Neil, A. (2008). Personality as predictor of Work Related Behaviour and Performance: Recent advances and directions for future. International Review of Industrial and Organizational Psychology. Edited by G.P. Hodgkinson \& J. K. Ford. Vol. 23

Cattell, H. E. P., \& Alan, D. M. (2008). The Sage Handbook of Personality Theory Assessment, 135159.

Chen, E., (2004). Why Socioeconomic Status Affects the Health of Children: A Psychosocial Perspective. A Journal of the Association for Psychological Science, 13(3), 112-115

Colquitt, J., Le-Pine, J., \& Wesson, M. (2009). Organizational Behavior; improving performance and commitment in the workplace. New York, McGraw-Hill, Irwin

Emecheta, B. C., Awa, H. O., \& Ukoha, O. (2016). Personality Characteristics and Employee Affective Commitment: Nigeria Experience. International Journal of Business and Management Review, 4(6), 69-92

Fisher, D. M., Suzanne, T. B., Erich C. ., \& James, A .B., (2012), "Facet Personality and Surface-Level Diversity as Team Mental Model Antecedents: Implications for Implicit Coordination, " Journal of Applied Psychology, 97(4) 825-841

Golberg, L. R. (1992). The development of markers for the Big-Five factor structure. Psychological Assessment, 4: 26-42

Howard, P. J., \& Howard, J. M. (1995). The Big Five Quick Start: An introduction to the five factor model of personality for human resource professionals. ED 384754, Centre of applied cognitive studies, Charlotte, North Carolina.

Judge, T. A., Bono, J. E., Ilies, R., \& Gerhardt, M. W. (2000). Personality and leadership a qualitative and quantitative review. Journal of Applied Psychology, 87, 765-780

Kinicki. (2008), Organizational Behavior: Core Concepts. New York, McGraw-Hill Irwin Knowledge, and Management, 12, 139-157Knowledge, and Management, 12, 139-157.

Katzenbach, J. R., and Smith, D. K. (1993), The Wisdom of Teams: Creating the High-performance Organisation, Harvard Business School, Boston.

Toward, N. W. T. (1963) an adequate taxonomy of personality attributes: Replicated factor structure in peer nomination personality ratings. The Journal of Abnormal and Social Psychology. 66(6), 574

Miller, A. (2015). Death of a salesman. Bloomsbury Publishing. Retrieved from https://books.google.com/books?id=ZzSTCgAAQBAJ\&printsec=frontcover\&dq=Death+of+a+Sa lesm

Salas, E., Stagl, K. C., \& Burke, C. S. (2004). 25 years of team effectiveness in organizations: Research themes and emerging needs. In C.L. Cooper, \& I. T Robertson (Eds.), International Review of Industrial and Organizational Psychology, 19 (pp. 47-91)..

Orthogonal, S. G. (2002) markers for orthogonal factors: The case of the big five. Journal of Research in Personality. 36(1):1-31

Waheed, A., Yang, J., \& Webber, J. (2017). The effect of personality traits on sales performance: An empirical investigation to test the five-factor model (FFM) in Pakistan. Interdisciplinary Journal of Information.

William, R. F., \& Tashchian, A. (2017) Modeling the Effects of Personality on Performance Outcomes in Student Teams. International Journal of Business and Social Science, 8( 5), 
INTERNATIONAL JOURNAL OF ACADEMIC RESEARCH IN BUSINESS AND SOCIAL SCIENCES Vol. 10, No. 10, 2020, E-ISSN: 2222-6990 @ 2020 HRMARS

Zimmerman, R. D. (2008). Understanding the impact of personality traits on individuals' turnover decisions: A meta-analytic path model. Personnel Psychology.;61:309-348. 